\title{
Distribution of cysteinyl leukotriene receptor 2 in human traumatic brain injury and brain tumors ${ }^{1}$
}

\author{
Hua $\mathrm{HU}^{2,3}$, Gao $\mathrm{CHEN}^{2}$, Jian-min ZHANG ${ }^{2}$, Wei-ping ZHANG ${ }^{3}$, Lei ZHANG ${ }^{3}$, Qiu-fu GE ${ }^{3}$, Hong-tian YAO ${ }^{4}$, Wei DING ${ }^{4}, \mathrm{Zhong}^{3}$ \\ $\mathrm{CHEN}^{3}$, Er-qing WEI ${ }^{3,5}$ \\ ${ }^{2}$ Department of Neurosurgery, the Second Affiliated Hospital, School of Medicine, Zhejiang University, Hangzhou 310009; ${ }^{3}$ Department of \\ Pharmacology, School of Medicine, Zhejiang University, Hangzhou 310031; ${ }^{4}$ Department of Pathology, the First Affiliated Hospital, School \\ of Medicine, Zhejiang University, Hangzhou 310003, China
}

\section{Key words}

cysteinyl leukotriene receptor 2 ; brain injuries; brain neoplasms; vascular smooth muscle cell

\footnotetext{
${ }^{1}$ Project supported by the National Natural Science Foundation of China (№ 30271498) and the National Basic Research Program of China (No G1999054000).

${ }^{5}$ Correspondence to Prof Er-qing WEI.

Phn 86-571-8721-7391.

Fax 86-571-8721-7044.

E-mailweieq2001@yahoo.com
}

Received 2004-11-01

Accepted 2005-04-05

doi: $10.1111 / \mathrm{j} .1745-7254.2005 .00092 . x$

\begin{abstract}
Aim: To determine the distribution of cysteinyl leukotriene receptor $2\left(\mathrm{CysLT}_{2}\right)$, one of the cysteinyl leukotriene receptors, in human brains with traumatic injury and tumors. Methods: Brain specimens were obtained from patients who underwent brain surgery. CysLT $_{2}$ in brain tissues was examined using immunohistochemical analysis. Results: CysLT $_{2}$ was expressed in the smooth muscle cells (not in the endothelial cells) of arteries and veins. CysLT 2 was also expressed in the granulocytes in both vessels and in the brain parenchyma. In addition, $\mathrm{CysLT}_{2}$ was detected in neuron- and glial-appearing cells in either the late stages of traumatic injury or in the area surrounding the tumors. Microvessels regenerated $8 \mathrm{~d}$ after trauma and $\mathrm{CysLT}_{2}$ expression was recorded in their endothelial cells. Conclusion: CysLT $_{2}$ is distributed in vascular smooth muscle cells and granulocytes, and brain trauma and tumor can induce its expression in vascular endothelial cells and in a number of other cells.
\end{abstract}

\section{Introduction}

Cysteinyl leukotrienes (CysLTs), including $\mathrm{LTC}_{4}, \mathrm{LTD}_{4}$ and $\mathrm{LTE}_{4}$, are potent inflammatory mediators. In peripheral inflammatory diseases such as asthma and rhinitis, CysLTs can induce smooth muscle constriction, microvascular leakage, eosinophilic recruitment and other responses ${ }^{[1-3]}$. In the central nervous system (CNS), the level of CysLTs increases after brain injuries such as cerebral ischemia, brain trauma and tumors ${ }^{[4-6]}$. The increase in CysLTs after traumatic brain injury peaks at $4 \mathrm{~h}$ and again at $7 \mathrm{~d}$, and is related to edema and cellular inflammatory responses in the rat brain ${ }^{[5]}$. In addition, the increase in CysLTs in metastatic tumors and gliomas is considered to be a factor promoting peritumoural edema $^{[4,7]}$.

The cloned CysLT receptors include $\mathrm{CysLT}_{1}$ and $\mathrm{CysLT}_{2}$, both of which are classic $\mathrm{G}$ protein-coupled receptors with seven transmembrane domains ${ }^{[8,9]}$. Human CysLT $_{2}$ is highly expressed in the spleen, placenta, heart, and peripheral blood leukocytes, and weakly expressed in the brain, prostate, skeletal muscle, kidney and ovary ${ }^{[8-10]}$. Using a ribonuclease protection assay, the highest expression of murine $\mathrm{CysLT}_{2}$ was detected in the spleen, adrenal gland and thymus, and weaker expression was recorded in the kidney, brain and peripheral blood leukocytes ${ }^{[11]}$. In human and murine brains CysLT $_{2}$ is expressed much more than CysLT $_{1}$ using Northern blot and RT-PCR ${ }^{[11,12]}$. However, the distribution of CysLT $\mathrm{CH}_{2}$ in the brains of animals including humans is still unknown.

Recently, we examined CysLT ${ }_{1}$ expression in human brain specimens from patients with traumatic brain injury and brain tumors $^{[13]}$. We found that CysLT $_{1}$ is mainly distributed in the vascular endothelium, which is consistent with the inhibiting effects of $\mathrm{CysLT}_{1}$ antagonists on plasma extravasation and brain edema in the brains of focal cerebral ischemic rats ${ }^{[14]}$. In the present study, we examined the distribution of CysLT $\mathrm{CH}_{2}$ in human brains after traumatic injury and in brains with tumors. 


\section{Materials and methods}

Human brain specimens This study was approved by the ethics committee of the Second Affiliated Hospital, School of Medicine, Zhejiang University, Hangzhou, China. Brain specimens were obtained from 24 patients who underwent brain surgery because of traumatic brain injury, brain tumors, or benign meningioma (Table 1). The diagnosis of each patient with brain tumor was based on criteria pertaining to the clinical MRI picture, appropriate laboratory data and biopsy findings. Astrocytomas and gangliogliomas were classified as low (grades I-II) or high (grades III-IV) grade according to the Daumas-Duport criteria.

Immunohistochemistry Brain tissues were fixed in 4\% formaldehyde for $24-48 \mathrm{~h}$, and then embedded in paraffin. A $6 \mu \mathrm{m}$ thick paraffin section was stained with hematoxylin and eosin (HE). Another section was incubated with a primary polyclonal antibody against $\mathrm{CysLT}_{2}$ for $1 \mathrm{~d}$ at $4{ }^{\circ} \mathrm{C}(5 \mathrm{mg} / \mathrm{L}$, rabbit IgG, Cayman, USA). This section was sequentially treated with anti-rabbit IgG biotinylated secondary antibody and avidin biotin complex (Zymed, USA). Finally, the section was visualized with $0.01 \%$ diaminobenzidine tetrahydrochloride (DAB) and $0.005 \% \mathrm{H}_{2} \mathrm{O}_{2}$ in $50 \mathrm{mmol} / \mathrm{L}$ Tris- $\mathrm{HCl}$, $\mathrm{pH}$ 7.6. Control sections were treated with normal goat serum instead of the primary antibody to test the specificity of the immunohistochemical reaction. Nuclei of cells were counter stained using hematoxylin.

\section{Results}

The control sections treated with normal goat serum showed no positive immunostaining (data not shown). CysLT $_{2}$ was highly expressed in the smooth muscle cells of both arteries and veins, but not in the endothelial cells (Figure 1A,1B). Brain tissues surrounding benign meningioma appeared relatively normal using MRI and HE staining (data not shown). In such relatively normal brain tissues, $\mathrm{CysLT}_{2}$ was not detected in microvascular endothelial cells or in other cells (Figure 1C, Table 1).

CysLT $_{2}$ expression in human brains after traumatic injury Within $3 \mathrm{~d}$ after traumatic brain injury, mild expression of CysLT 2 was frequently detected in the neuron- and glialappearing cells in a number of human brain specimens (Figure $2 \mathrm{~A}$, Table 1), but rarely in the microvascular endothelial cells (Figure 2B, Table 1). However, $8 \mathrm{~d}$ after trauma, microvascular regeneration was observed and $\mathrm{CysLT}_{2}$ was highly expressed in the regenerated microvascular endothelial cells and glial-appearing cells (Figure 2C, Table 1), but no CysLT 2 positive cell was found in the necrotic regions (Figure 2D). In addition, in one patient, MPO-positive granulocytes were found within vessels and in the brain parenchyma (data not shown), and $\mathrm{CysLT}_{2}$ was highly expressed in the granulocytes both within vessels (Figure 2E) and in the brain parenchyma (Figure 2F).

CysLT $_{2}$ expression in human brain tumors In brain tumors, no $\mathrm{CysLT}_{2}$ was detected in the center of glioma, ganglioglioma and metastatic carcinomas (Figure 3A,3B, Table 1), but strong CysLT $_{2}$ immunostaining was found in neuron- and glial-apprearing cells surrounding tumors (Figure 3C, Table 1).

\section{Discussion}

In this study, the first finding is the specific distribution pattern of $\mathrm{CysLT}_{2}$ in brain vessels. $\mathrm{CysLT}_{2}$ was highly ex-
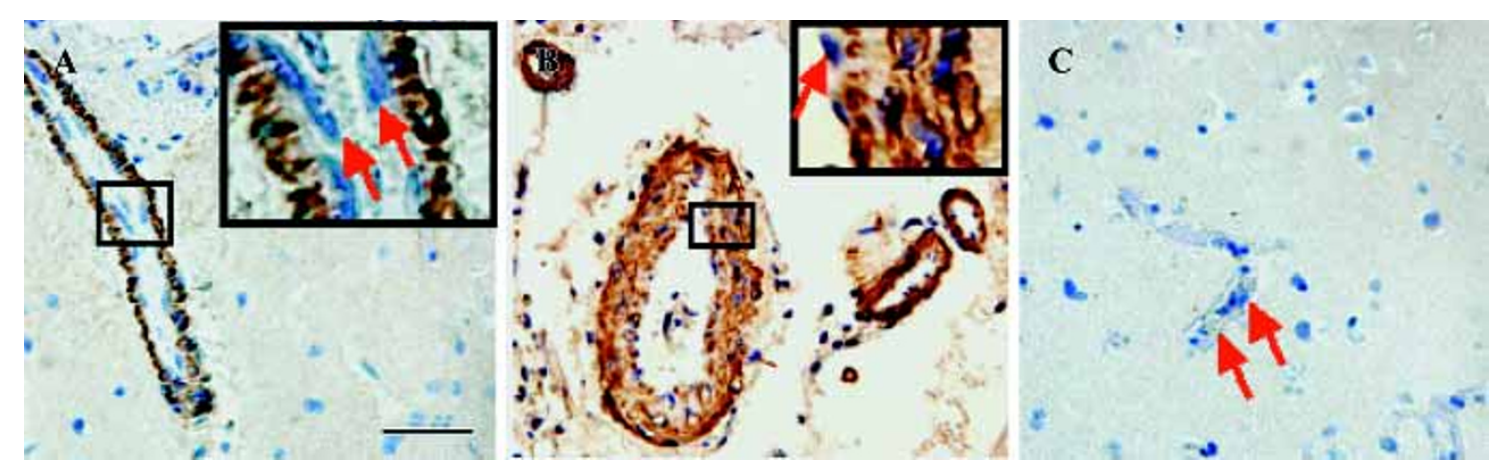

Figure 1. CysLT $\mathrm{C}_{2}$ expression in the vessels of the human brain. Brain samples were obtained from two patients with astrocytoma (Patient numbers 21 and 22 from Table 1 in $\mathrm{A}$ and B, respectively) and one patient with benign meningioma (Patient number 1 from Table 1 in $\mathrm{C}$ ).

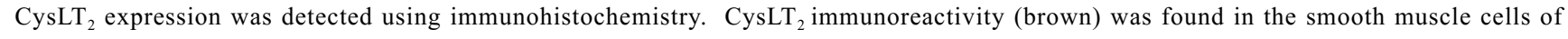
veins (A) and arteries (B), but not in endothelial cells (red arrows), microvascular endothelial cells (C, red arrows) or other cells within the brain tissues. The inserts are amplifications from the black boxes in A and B. Scale bar is $50 \mu \mathrm{m}$. 
Table 1. Patient profiles and the immunohistochemical results for $\mathrm{CysLT}_{2}$. NA, not applicable; -, absent; \pm , weak or few; + , mild; ++ , marked; ?, not detected; L, left; R, right; T, temporal lobe; F, frontal lobe; P, parietal lobe. Samples were from the tissues surrounding (*) and within $(* *)$ the injured regions or the tumors; NAC, neuron-appearing cells; GAC, glial-appearing cells; VEC, microvascular endothelial cells.

\begin{tabular}{|c|c|c|c|c|c|c|c|c|c|c|c|}
\hline & \multirow{2}{*}{$\begin{array}{l}\text { Patient } \\
\text { number }\end{array}$} & \multirow[t]{2}{*}{ Age/sex } & \multirow{2}{*}{$\begin{array}{c}\text { Duration } \\
\text { from onset }\end{array}$} & \multirow{2}{*}{$\begin{array}{l}\text { Side/ } \\
\text { lobes }\end{array}$} & \multirow[t]{2}{*}{ Grade } & \multicolumn{3}{|c|}{ Adjacent to lesions* } & \multicolumn{3}{|c|}{ Center of lesions** } \\
\hline & & & & & & NAC & GAC & VEC & NAC & GAC & VEC \\
\hline \multicolumn{12}{|l|}{ Control samples } \\
\hline $\begin{array}{l}\text { Beside benign } \\
\text { meningioma }\end{array}$ & 1 & $51 / \mathrm{F}$ & NA & $\mathrm{L} / \mathrm{T}$ & NA & - & - & - & NA & NA & NA \\
\hline \multirow{15}{*}{$\begin{array}{l}\text { Traumatic brain } \\
\text { injury }\end{array}$} & 2 & $55 / \mathrm{M}$ & $6 \mathrm{~h}$ & $\mathrm{R} / \mathrm{T}$ & NA & NA & NA & NA & - & - & - \\
\hline & 3 & $15 / F$ & $9 \mathrm{~h}$ & $\mathrm{~L} / \mathrm{T}$ & NA & NA & NA & NA & - & - & - \\
\hline & 3 & $51 / \mathrm{M}$ & $9 \mathrm{~h}$ & $\mathrm{~L} / \mathrm{T}$ & NA & NA & NA & NA & \pm & \pm & - \\
\hline & 4 & $26 / \mathrm{F}$ & $9 \mathrm{~h}$ & $\mathrm{R} / \mathrm{F}$ & NA & NA & NA & NA & - & - & - \\
\hline & 5 & $30 / \mathrm{M}$ & $14 \mathrm{~h}$ & $\mathrm{R} / \mathrm{P}$ & NA & NA & NA & NA & \pm & \pm & - \\
\hline & 6 & $52 / \mathrm{M}$ & $15 \mathrm{~h}$ & $\mathrm{R} / \mathrm{T}$ & NA & NA & NA & NA & - & - & \pm \\
\hline & 7 & $49 / \mathrm{M}$ & $20 \mathrm{~h}$ & $\mathrm{R} / \mathrm{L} / \mathrm{F}$ & NA & NA & NA & NA & - & - & - \\
\hline & 8 & $52 / \mathrm{M}$ & $24 \mathrm{~h}$ & $\mathrm{R} / \mathrm{L} / \mathrm{F}$ & NA & NA & NA & NA & - & - & \pm \\
\hline & 9 & $21 / \mathrm{M}$ & $24 \mathrm{~h}$ & $\mathrm{R} / \mathrm{L} / \mathrm{F}$ & NA & NA & NA & NA & \pm & \pm & - \\
\hline & 10 & $41 / \mathrm{M}$ & $24 \mathrm{~h}$ & $\mathrm{R} / \mathrm{F}$ & NA & NA & NA & NA & - & - & - \\
\hline & 11 & $51 / \mathrm{M}$ & $24 \mathrm{~h}$ & $\mathrm{R} / \mathrm{F}$ & NA & NA & NA & NA & - & - & - \\
\hline & 12 & $57 / F$ & $30 \mathrm{~h}$ & $\mathrm{~L} / \mathrm{F}$ & NA & NA & NA & NA & \pm & \pm & - \\
\hline & 13 & $71 / \mathrm{M}$ & $2.5 \mathrm{~d}$ & $\mathrm{R} / \mathrm{T}$ & NA & NA & NA & NA & \pm & \pm & - \\
\hline & 14 & $21 / \mathrm{F}$ & $3 \mathrm{~d}$ & $\mathrm{~L} / \mathrm{T}$ & NA & NA & NA & NA & \pm & \pm & - \\
\hline & 15 & $39 / \mathrm{M}$ & $8 \mathrm{~d}$ & $\mathrm{R} / \mathrm{T}$ & NA & NA & NA & NA & $?$ & ++ & ++ \\
\hline \multirow[t]{7}{*}{ Astrocytoma } & 16 & $42 / \mathrm{F}$ & NA & $\mathrm{L} / \mathrm{P}$ & II & ++ & ++ & $?$ & $?$ & - & - \\
\hline & 17 & $38 / \mathrm{F}$ & NA & $\mathrm{R} / \mathrm{T}$ & III & ++ & ++ & $?$ & $?$ & - & - \\
\hline & 18 & $82 / \mathrm{M}$ & NA & $\mathrm{L} / \mathrm{T}$ & III & ++ & ++ & $?$ & $?$ & - & - \\
\hline & 19 & $64 / \mathrm{M}$ & NA & $\mathrm{L} / \mathrm{P}$ & II & ++ & ++ & $?$ & $?$ & - & - \\
\hline & 20 & $29 / F$ & NA & $\mathrm{L} / \mathrm{F}$ & II & ++ & ++ & $?$ & $?$ & - & - \\
\hline & 21 & $38 / \mathrm{M}$ & $5 \mathrm{y}$ & $\mathrm{L} / \mathrm{T}$ & II & ++ & ++ & $?$ & $?$ & - & - \\
\hline & 22 & $71 / \mathrm{M}$ & $2 y$ & $\mathrm{~L} / \mathrm{T}$ & II & ++ & ++ & $?$ & $?$ & - & - \\
\hline Ganglioglioma & 23 & $52 / \mathrm{M}$ & NA & $\mathrm{L} / \mathrm{T}$ & II & ++ & ++ & $?$ & $?$ & - & - \\
\hline $\begin{array}{l}\text { Metastatic } \\
\text { carcinoma }\end{array}$ & 24 & $55 / \mathrm{M}$ & NA & $\mathrm{L} / \mathrm{T}$ & NA & ++ & ++ & $?$ & - & - & - \\
\hline
\end{tabular}

pressed in the smooth muscle cells of arteries and veins, but rarely in vascular and microvascular endothelial cells in relatively normal brain tissues or in tissues within $3 \mathrm{~d}$ of brain trauma. This pattern is different from that of $\mathrm{CysLT}_{1}$, which is primarily expressed in endothelial cells as found in our previous study ${ }^{[13]}$. However, strong expression of $\mathrm{CysLT}_{2}$ was found in the regenerated microvascular endothelial cells $8 \mathrm{~d}$ after trauma, suggesting an inducible $\mathrm{CysLT}_{2}$ expression. This result is similar to that of the human heart, in which $\mathrm{CysLT}_{2}$ mRNA has been detected in myocytes, fibroblasts and vascular smooth muscle cells, but not in endothelial cells $^{[15]}$. Moreover, CysLT $_{2}$ has been reported to be expressed primarily in human umbilical vein endothelial cells (HUVECs) ${ }^{[16]}$, and may play a role in inflammation during atherogenesis or leukocyte infiltration into tissues ${ }^{[17]}$. A recent study using $\mathrm{CysLT}_{2}$-deficient mice confirmed that $\mathrm{CysLT}_{2}$ mediates an increase in vascular permeability in IgE-dependent passive cutaneous anaphylaxis $^{[18]}$. Our present results showed that unlike peripheral tissues (HUVECs), CysLT $_{2}$ was only expressed in the endothelial cells of injured brain tissues after a longer duration. This result implies that $\mathrm{CysLT}_{2}$ might be involved in inflammatory responses in the CNS.

The second finding of this study is the inducible $\mathrm{CysLT}_{2}$ expression in neuron- and glial-appearing cells after brain trauma and in brain tumors. We have recently reported inducible CysLT $_{1}$ expression in neuron- and glial-appearing 

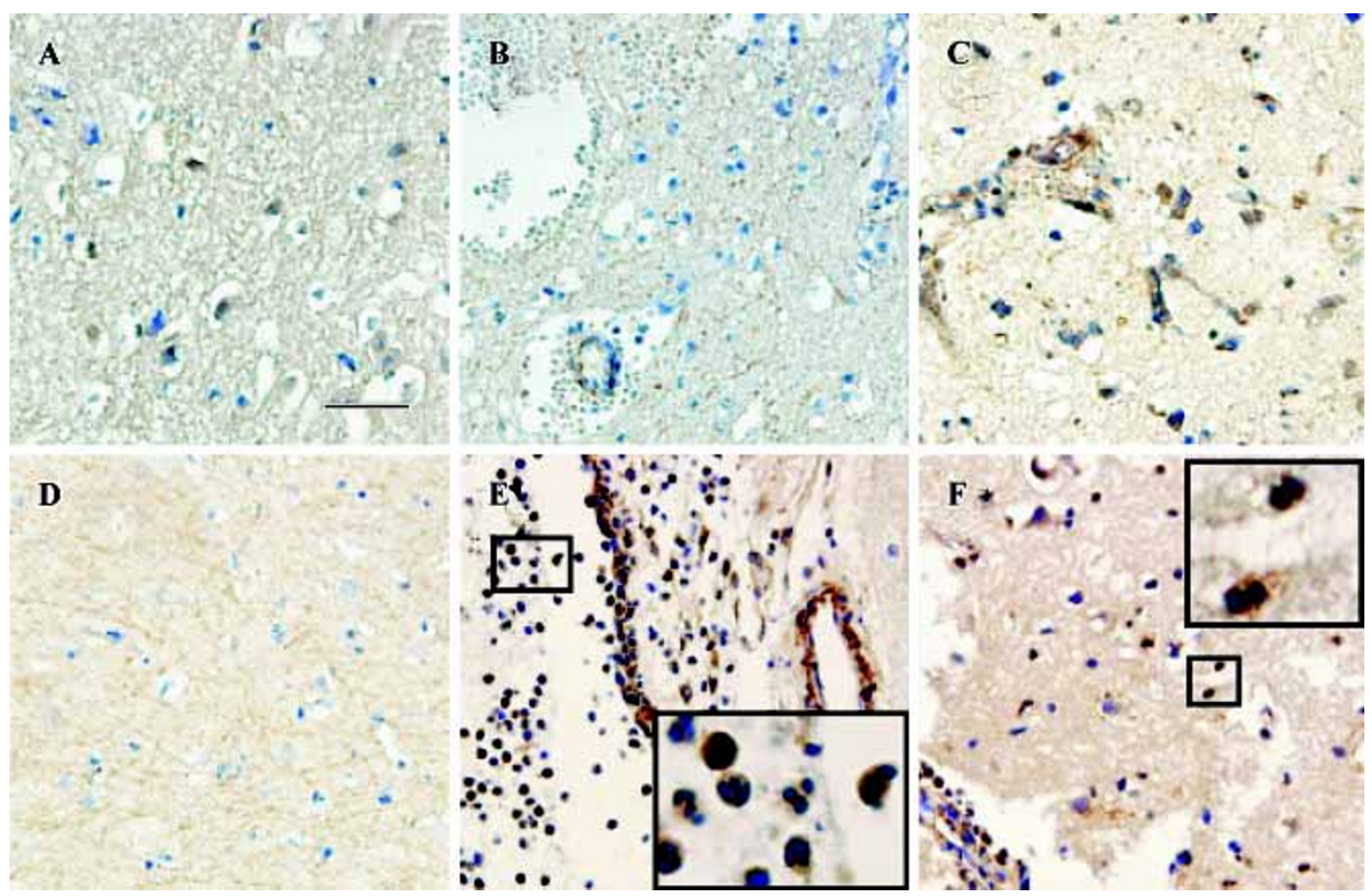

Figure 2. CysLT2 expression in human brains after traumatic brain injury. Brain samples were from patients $14 \mathrm{~h}$ (A; patient number 5 ), 15 h (B, E, F; patient number 6), or $8 \mathrm{~d}(\mathrm{C}, \mathrm{D}$; patient number 15$)$ after traumatic brain injury. At 14 or $15 \mathrm{~h}$ after injury, mild expression of CysLT2 were found in neuron- and glial-appearing cells (A), and in microvascular endothelial cells (B). At $8 \mathrm{~d}$ after injury, microvessels had regenerated, and CysLT2 was highly expressed in the microvascular endothelial cells, glial-appearing cells and granulocytes (C), but not in the necrotic region (D). CysLT2 was also highly expressed in granulocytes both within vessels (E) and within brain tissues (F). The inserts are amplifications from the black boxes in E and F. Scale bar is $50 \mu \mathrm{m}$.
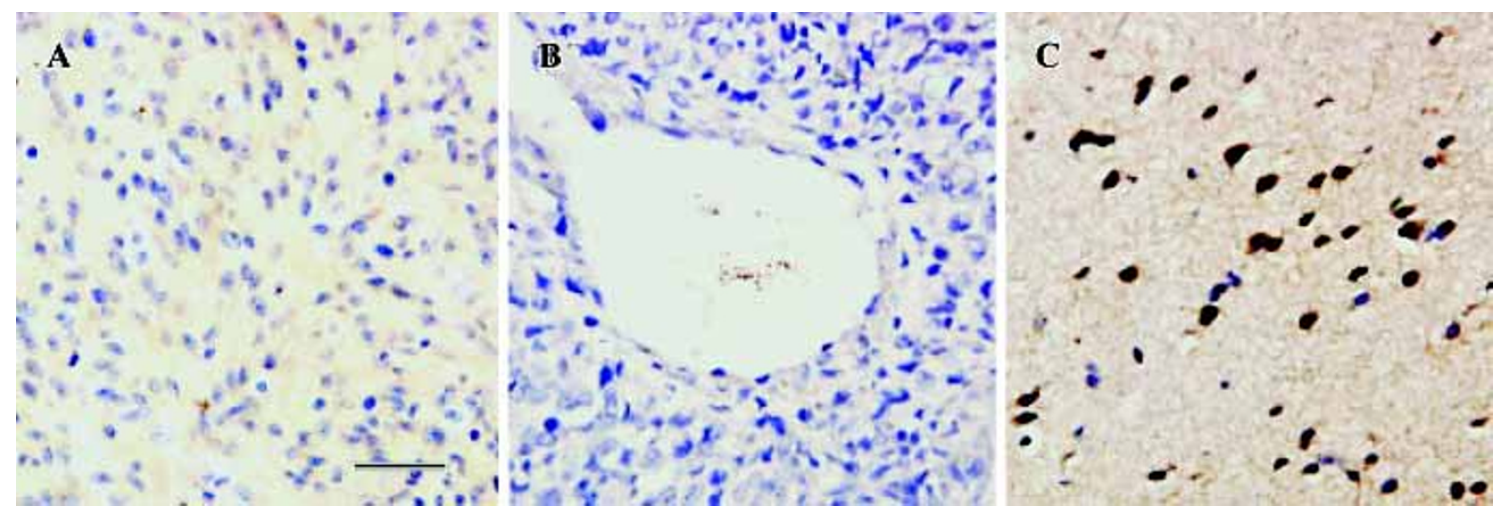

Figure 3. CysLT $_{2}$ expression in human brains with tumors. Samples were obtained from patients with astrocytoma (A, C; patient number 19) or metastatic carcinoma (B; patient number 24). CysLT 2 was not found within astrocytomas (A) or metastatic carcinomas (B), but was highly expressed in neuron- and glial-appearing cells surrounding the astrocytoma (C). Scale bar is $50 \mu \mathrm{m}$.

cells after traumatic brain injury and brain tumors ${ }^{[13]}$. Unlike $\mathrm{CysLT}_{1}$, the inducible $\mathrm{CysLT}_{2}$ expression in these cells was much reduced within $3 \mathrm{~d}$ after trauma, but was strong $8 \mathrm{~d}$ after trauma and surrounding the tumors. The pathophysiological implications of $\mathrm{CysLT}_{2}$ in the brain are unknown, but $\mathrm{CysLT}_{2}$ may be involved in intracerebral cell proliferation because CysLTs can promote astrocyte and intestinal epithelial cell proliferation ${ }^{[1,20]}$. Recently it has been reported that bleomycin-induced pulmonary fibrosis is increased in $\mathrm{CysLT}_{1}$-deficient mice, but decreased in $\mathrm{CysLT}_{2}$-deficient- 
mice $^{[18,21]}$. Therefore, the inducible CysLT $_{2}$ expression $8 \mathrm{~d}$ after trauma might be responsible for cell regeneration and/ or proliferation.

In addition, $\mathrm{CysLT}_{2}$ was highly expressed in the granulocytes in both vessels and brain tissues. This result is consistent with previous reports that show that $\mathrm{CysLT}_{2}$ is expressed in peripheral blood leukocytes ${ }^{[10]}$ and is responsible for chemotaxis ${ }^{[22]}$. However, according to the results of guinea pig brain perfusion with human neurtrophils, Di Gennaro et $a l^{[23]}$ hypothesized that $\mathrm{CysLT}_{1}$ in leukocytes and $\mathrm{CysLT}_{2}$ in endothelial cells might be involved in the adherence and intrusion of leukocytes in brain inflammatory reactions. However, our results examining the distributions of CysLT $\mathrm{C}_{1}$ and $\mathrm{CysLT}_{2}$ in human brains do not support their hypothesis.

In summary, we found that $\mathrm{CysLT}_{2}$ was expressed in smooth muscle cells and granulocytes, suggesting that $\mathrm{CysLT}_{2}$ might play a role in cerebral circulation and the inflammatory response that occurs in human brains after injury. The induced $\mathrm{CysLT}_{2}$ expression in microvascular endothelial cells, and neuron- or glial-appearing cells after traumatic injury and in brain tumors requires further investigation.

\section{Acknowledgment}

We thank Prof Pei-hui CHEN from the Department of Pathology, the Second Affiliated Hospital, School of Medicine, Zhejiang University, for his help with the analysis of brain sections.

\section{References}

1 Borish L. The role of leukotrienes in upper and lower airway inflammation and the implications for treatment. Ann Allergy Asthma Immunol 2002; 88: 16-22.

2 Fujita M, Yonetomi Y, Shimouchi K, Takeda H, Aze Y, Kawabata $\mathrm{K}$, et al. Involvement of cysteinyl leukotrienes in biphasic increase of nasal airway resistance of antigen-induced rhinitis in guinea pigs. Eur J Pharmacol 1999; 369: 349-56.

3 Storms WW. Minimal persistent inflammation, an emerging concept in the nature and treatment of allergic rhinitis: the possible role of leukotrienes. Ann Allergy Asthma Immunol 2003; 91: 131-40.

4 Shinonaga M, Chang CC, Kuwabara T. Relation between macrophage infiltrates and peritumoral edema. Adv Neurol 1990; 52: 475-81.

5 Schuhmann MU, Mokhtarzadeh M, Stichtenoth DO, Skardelly M, Klinge PM, Gutzki FM, et al. Temporal profiles of cerebrospinal fluid leukotrienes, brain edema and inflammatory response following experimental brain injury. Neurol Res 2003; 25: 481-91.

6 Ciceri P, Rabuffetti M, Monopoli A, Nicosia S. Production of leukotrienes in a model of focal cerebral ischaemia in the rat. $\mathrm{Br}$
J Pharmacol 2001; 133: 1323-9.

7 Inamura $\mathrm{T}$, Abe M, Ikezaki K, Fukui M. Leukotriene $\mathrm{C}_{4}$ contents, synthase and catabolic activity in human meningiomas. Neurol Res 1992; 14: 405-10.

8 Lynch KR, O’Neill GP, Liu Q, Im DS, Sawyer N, Metters KM, et al. Characterization of the human cysteinyl leukotriene CysLT receptor. Nature 1999; 399: 789-93.

9 Sarau HM, Ames RS, Chambers J, Ellis C, Elshourbagy N, Foley $\mathrm{JJ}$, et al. Identification, molecular cloning, expression, and characterization of a cysteinyl leukotriene receptor. Mol Pharmacol 1999; 56: 657-63.

10 Takasaki J, Kamohara M, Matsumoto M, Saito T, Sugimoto T, Ohishi T, et al. The molecular characterization and tissue distribution of the human cysteinyl leukotriene $\mathrm{CysLT}_{2}$ receptor. Biochem Biophys Res Commun 2000; 274: 316-22.

11 Hui Y, Yang G, Galczenski H, Figueroa DJ, Austin CP, Copeland $\mathrm{NG}$, et al. The murine cysteinyl leukotriene $2 \mathrm{CysLT}_{2}$ receptor. cDNA and genomic cloning, alternative splicing, and in vitro characterization. J Biol Chem 2001; 276: 47489-95.

12 Heise CE, O'Dowd BF, Figueroa DJ, Sawyer N, Nguyen T, Im DS, et al. Characterization of the human cysteinyl leukotriene 2 receptor. J Biol Chem 2000; 275: 30531-6.

13 Zhang WP, Hu H, Zhang L, Ding W, Yao HT, Chen KD, et al. Expression of cysteinyl leukotriene receptor 1 in human traumatic brain injury and brain tumors. Neurosci Lett 2004; 363 : 247-51.

14 Zhang WP, Wei EQ, Mei RH, Zhu CY, Zhao MH. Neuroprotective effect of ONO-1078, a leukotriene receptor antagonist, on focal cerebral ischemia in rats. Acta Pharmacol Sin 2002; 23: 871-7.

15 Kamohara M, Takasaki J, Matsumoto M, Matsumoto S, Saito T, Soga $\mathrm{T}$, et al. Functional characterization of cysteinyl leukotriene $\mathrm{CysLT}_{2}$ receptor on human coronary artery smooth muscle cells. Biochem Biophys Res Commun 2001; 287: 1088-92.

16 Sjostrom M, Johansson AS, Schroder O, Qiu H, Palmblad J, Haeggstrom JZ. Dominant expression of the CysLT 2 receptor accounts for calcium signaling by cysteinyl leukotrienes in human umbilical vein endothelial cells. Arterioscler Thromb Vasc Biol 2003; 23: e37-41.

17 Lotzer K, Spanbroek R, Hildner M, Urbach A, Heller R, Bretschneider E, et al. Differential leukotriene receptor expression and calcium responses in endothelial cells and macrophages indicate 5-lipoxygenase-dependent circuits of inflammation and atherogenesis. Arterioscler Thromb Vasc Biol 2003; 23: e32-6.

18 Beller TC, Maekawa A, Friend DS, Austen KF, Kanaoka Y. Targeted gene disruption reveals the role of the cysteinyl leukotriene 2 receptor in increased vascular permeability and in bleomycininduced pulmonary fibrosis in mice. J Biol Chem 2004; 279 : 46129-34.

19 Ciccarelli R, D'Alimonte I, Santavenere C, D'Auro M, Ballerini $\mathrm{P}$, Nargi E, et al. Cysteinyl-leukotrienes are released from astrocytes and increase astrocyte proliferation and glial fibrillary acidic protein via $\mathrm{CysLT}_{1}$ receptors and mitogen-activated protein kinase pathway. Eur J Neurosci 2004; 20: 1514-24.

20 Paruchuri S, Hallberg B, Juhas M, Larsson C, Sjolander A. Leukotriene $\mathrm{D}_{4}$ activates MAPK through a ras-independent but PKC \&-dependent pathway in intestinal epithelial cells. J Cell Sci 2002; 115: 1883-93. 
21 Beller TC, Friend DS, Maekawa A, Lam BK, Austen KF, Kanaoka Y. Cysteinyl leukotriene 1 receptor controls the severity of chronic pulmonary inflammation and fibrosis. Proc Natl Acad Sci USA 2004; 101: 3047-52.

22 Evans JF. Cysteinyl leukotriene receptors. Prostaglandins Lipid Mediators 2002; 68-69: 587-97.
23 Di Gennaro A, Carnini C, Buccellati C, Ballerio R, Zarini S, Fumagalli $\mathrm{F}$, et al. Cysteinyl-leukotrienes receptor activation in brain inflammatory reactions and cerebral edema formation: A role for transcellular biosynthesis of cysteinyl-leukotrienes. FASEB J 2004; 18: 842-4.

\title{
The First Scientific Meeting of the Asian Society for Vascular Biology
}

\author{
October 8-11, $2005 \quad$ Shanghai, China
}

Info: YuHUANG

Department of Physiology

Chinese University of Hong Kong

Hong Kong SAR, China

Phn 852-2609-6787

Fax 852-2603-5022

E-mail yu-huang@cuhk.edu.hk

http://www.sbsonline.org/sbscon/2005/index.php 